\title{
Mechanical Behavior and Optimization of Multidirectional Laminate Specimens under Delamination by Bending
}

\author{
A. Ahmed Benyahia, ${ }^{a}$ A. Laksimi, ${ }^{b}$ N. Ouali, ${ }^{a}$ and Z. Azari ${ }^{\mathrm{c}}$ \\ a Laboratoire de Mécanique Avancée, Alger, Algerie \\ ${ }^{\mathrm{b}}$ Laboratoire Roberval FRE-CNRS-6066, Compiègne, France \\ ${ }^{\mathrm{c}}$ Laboratoire de Fiabilité Mécanique, Metz, France
}

УДК 539.4

\section{Механическое поведение и оптимизация образцов из многомерных ламинатов в условиях деламинации при изгибе}

\author{
А. Ахмед Беньяхья \\ а Лаборатория прикладной механики, Алжир, Алжир \\ б Лаборатория им. Жиля Роберваля, Компьень, Франция \\ в Лаборатория механической надежности, Мец, Франция
}

При изгибном нагружении многомерных ламинатов имеет меспо деламинация, описание которой весьма затруднительно ввиду наличия больиих деформаций у вериинь трецинь и различных нелинейньхх эффектов, связанныл со значительньми перемечениями и образованием поперечньх микротрешин. Последние появляются в наиболее нагруженньх слоях, особенно в тонких лалинатах. Эксперилентально исследованы вылиеуказанные особенности на образиах в виде консольной балки и выполнена оптимизация толщины многослойного образиа, при которой деламинация начинается до образования поперечньх микротрецин в наиболее нагруженньх слоях. Объектол исследования служил стеклоэпоксидный упрочненный ламинат. Полученные результатьл оптимизации толщины образиов хороио согласуются с экспериментальными данныли.

Ключевые слова: многомерные ламинаты, деламинация, нелинейность, поперечные трещины, оптимизация по толщине.

Introduction. DCB specimen is the most specimen used for the characterization of delamination in Mode I of composite materials [1, 2]. Its geometry was optimized and standardized during the years 1990. However, this optimization was carried out for unidirectional laminates where the rupture of the plies by flexion is practically equivalent to tension load and where the delamination behavior remains insensitive to the thickness effect of the specimen.

Due to the embedding effect of the arms at the crack tip, a correction has been given to the analytical compliance relationship in order to take account of the deflection angle of the arms at the crack tip during bending [3-5]. However, the stress fields ahead of the crack tip and its effect on the mode of propagation of delamination has not been undertaken so far. It's obvious that the large displacement and the excessive angle of deflexion involve a non-linear behavior $[6,7]$. 
These problems of partial embedding of the arms and non-linearity affect the mechanical behavior of the multidirectional composites by generating additional dissipative phenomena such as transverse cracks of the strained plies especially in the case of large angles of the fibers orientation $[8,9]$. Consequently, this behavior makes the analysis of the experimental characterization results more difficult.

It is obvious that these problems depend on the specimen thickness, because in previous work [8] we found that the non-linear behavior of this material subjected to Mode II delamination by bending depends mainly on the thickness of the used test specimen. This is why, we propose in this study to highlight the problems caused in the case of multidirectional laminates and to find out the relationship which expresses this phenomenon. Then we propose an optimization of the thickness, which would ovoid the energy dissipation phenomena before starting of delamination.

\section{Experimental Analysis.}

1.1. Material and Experimental Conditions. The material used in this study is an E-glass/M10-epoxy composite. The fiber volume fraction is about $52 \%$. Test specimens were cut from plates of size $300 \times 300 \mathrm{~mm}$. A Teflon film $(30 \mathrm{~mm}$ in thickness) was incorporated at the mid-plane to initiate delamination (Fig. 1). The thickness of $5 \mathrm{~mm}$ is composed of 16 plies. The plates were cured in an air press according to the cure cycle recommended by the manufacturer ( 3 bars for 1 hour at $\left.120^{\circ} \mathrm{C}\right)$. Four configurations $[+\theta /-\theta /+\theta /-\theta /-\theta /+\theta /-\theta /+\theta]_{s}$ were selected with the angles: $\theta=15,30,45$ and $60^{\circ}$. Each specimen was instrumented by $10 \mathrm{~mm}$ strain gauges and a sensor of acoustic emission (AE) (Fig. 1) and loaded in displacement control at a constant rate $0.5 \mathrm{~mm} / \mathrm{min}$ in order to better see the occurrence of the damage initiation. The characteristics of the acoustic emission system are the following:

Pre-amplifier gain: $39 \mathrm{~dB}$.

Threshold setting: $39 \mathrm{~dB}$ for this study.

Filter pre-amplification: $45 \mathrm{~dB}$.

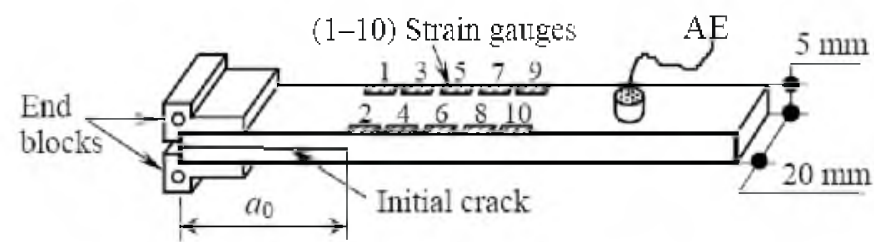

Fig. 1. Instrumentation of the DCB specimen by strain gauges and acoustic emission sensors.

The AE sensor used is a large frequency band from $200 \mathrm{kHz}$ to $1 \mathrm{MHz}$. The mechanical characteristics of the different sequences are indicated in Table 1.

1.2. Starting of Delamination. The instrumentation of the specimen by strain gauges and acoustic emission sensors (AE) are necessary to detect the microscopic delamination. This last technique (AE) enables us to identify the damage mechanisms which occur chronologically in the material. These results have been highlighted by microscopic observation (SEM). This experimental technique is described in $[7,9]$. The crack development for each stacking sequence were carried out in several stages. In each one, the mechanical load was 
followed by microscopic observations to identify the type of damage. Figure 2 and 3 show an example of load-displacement and microscopic observation of $\pm 15^{\circ}$ specimen. We can see that delamination starts and propagates in the median plane of the specimen. On the other hand, for the sequence $\pm 60^{\circ}$, the initial damage is a crack transverse of one of the two median plies (Figs. 4 and 5). Thus, for the first three sequences $\left( \pm 15^{\circ}, \pm 30^{\circ}\right.$, and $\left.\pm 45^{\circ}\right)$, delamination is the first type of occurring damage. We can then easily detect, on the curve of loaddisplacement, the point of delamination starting and calculate the strain energy release rate. On the other hand, in the case of the sequence $\pm 60^{\circ}$, the starting of delamination is preceded by transverse cracks. Consequently, calculation of the strain energy release rate will be inaccurate because the loss of energy dissipated by transverse cracks. These results correspond to a $5 \mathrm{~mm}$ thickness of the specimen. For a reliable characterization of delamination in any type of stacking sequence, it is necessary to avoid the occurrence of transverse cracking before the starting of delamination which can be obtained by increasing the flexional stiffness, i.e., the increasing thickness of the specimen.

$\mathrm{T}$ a b 1 e 1

Mechanical Characteristics of the Different Sequences

\begin{tabular}{|c|c|c|c|c|c|}
\hline Angle & 0 & $15^{\circ}$ & $30^{\circ}$ & $45^{\circ}$ & $60^{\circ}$ \\
\hline$E_{L}, \mathrm{GPa}$ & 44.110 & 39.300 & 27.640 & 18.470 & 16.430 \\
\hline$E_{T}, \mathrm{GPa}$ & 17.980 & 17.380 & 16.430 & 18.470 & 27.640 \\
\hline$G_{L T}, \mathrm{GPa}$ & 6.160 & 8.000 & 11.670 & 13.510 & 11.670 \\
\hline$v_{L T}$ & 0.267 & 0.367 & 0.512 & 0.490 & 0.310 \\
\hline
\end{tabular}

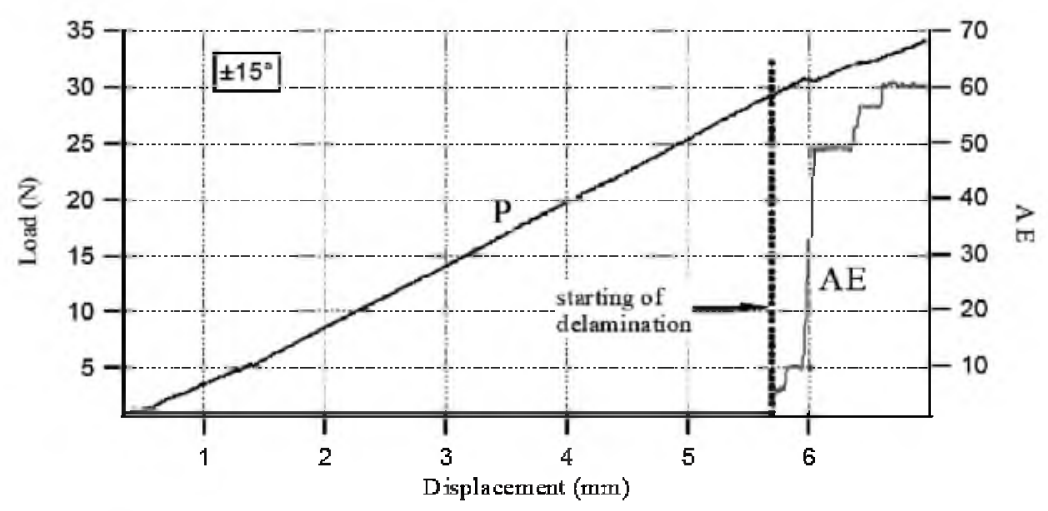

Fig. 2. Load and AE vs. displacement for $\pm 15^{\circ}$ sequence.

1.3. Deformations in Front of the Crack Tip. In order to better understand the behavior ahead of the crack tip, specimens have been instrumented by several strain gauges. The gauges have $10 \mathrm{~mm}$ length and are laid out with regular intervals of $1 \mathrm{~mm}$ of separation in the longitudinal direction of the specimen (Fig. 1). The response of these gauges is illustrated in Fig. 6a and $6 \mathrm{~b}$ for the sequences $\pm 15^{\circ}$ and $\pm 45^{\circ}$, respectively. The analysis of the response of these 
strain gauges shows that before macroscopic starting (line $B$ in dotted lines), only the gauges of the first series ( $J 1$ and $J 2)$ are sensitive to the applied loading. The strain gauges are more and more sensitive as soon as the delamination is about $10 \mathrm{~mm}$ from them. Focusing on these curves, this zone seems to be under compression which is located just in front of the crack tip, and generally appears on the external part of the arms of a specimen loaded in opening mode. This zone moves as a wave, forward the arm of the specimen with a speed equal to the crack tip propagation. The length of this wave depends on the mechanical and geometrical characteristics of the arm. This remark enables us to confirm that the arms of DCB specimen are not embedded perfectly at the crack tip. The strain energy release rate may be over-estimated, because it will contain an energy dissipated in front of the crack tip. In order to eliminate this phenomenon, it is necessary to minimize these strains in front of the crack tip by increasing the specimen stiffness.

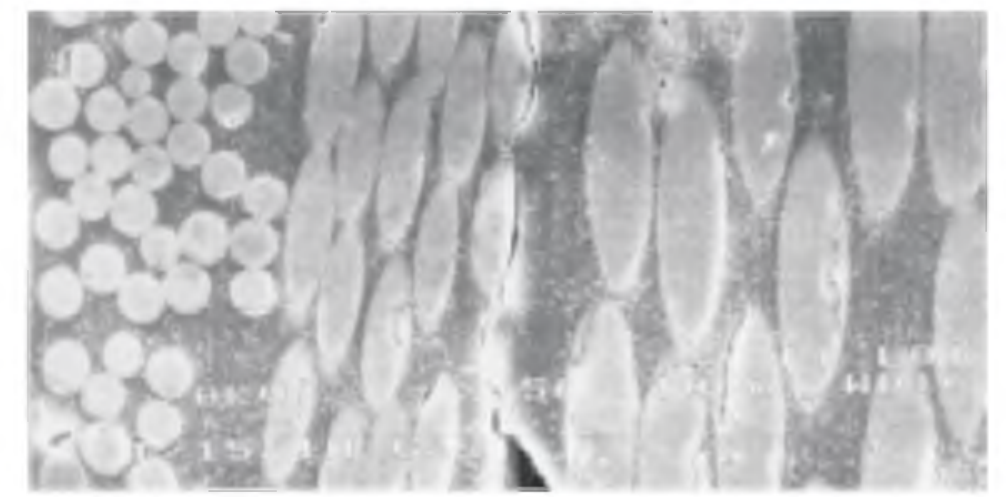

Fig. 3. Starting of damage by delamination in $\pm 15^{\circ}$ sequence.

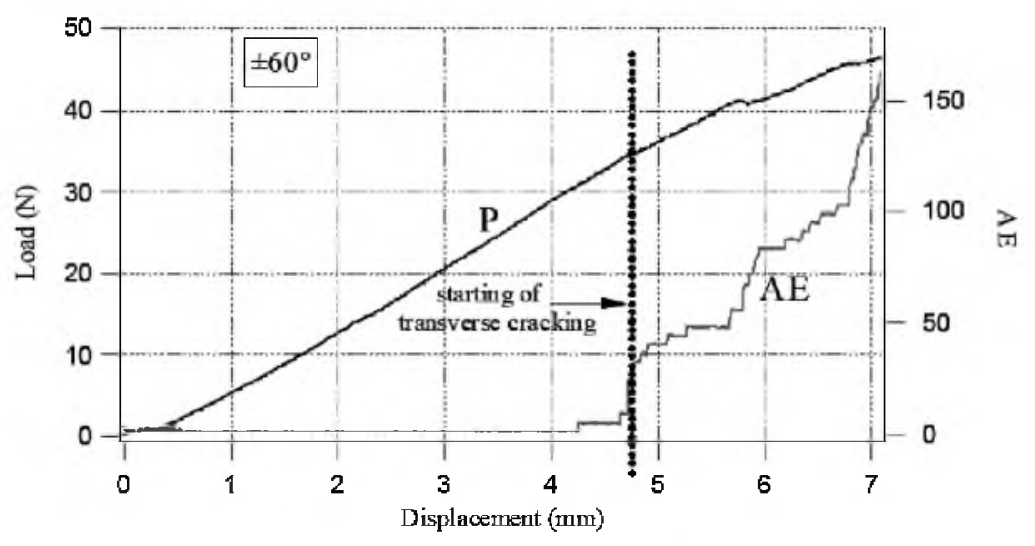

Fig. 4. Load and AE vs. displacement for $\pm 60^{\circ}$ sequence.

2. Thickness Optimization of DCB Specimen. It has been noticed that the strain energy release rate calculated experimentally is reliable if the specimen has a sufficient stiffness permitting the delamination starting before any other type of damage with a few possible strain in front of the crack tip. In the continuation of this work, stiffness optimization were carried out by using an analytical approach. 


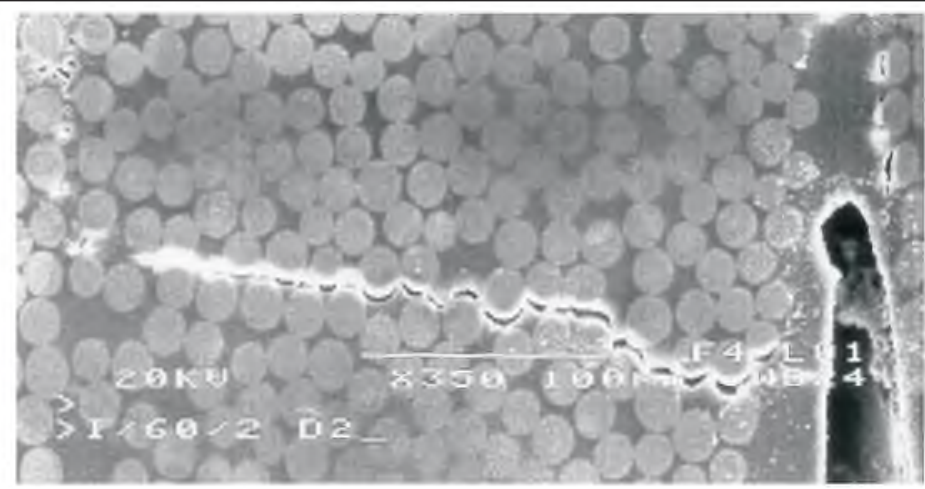

Fig. 5. Starting of damage by transverse cracking in $\pm 60^{\circ}$ sequence.

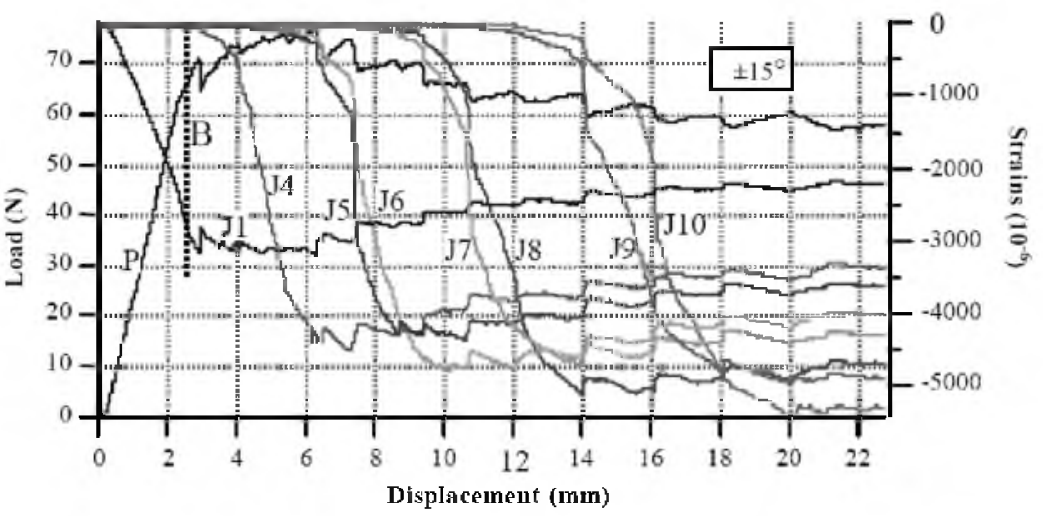

$a$

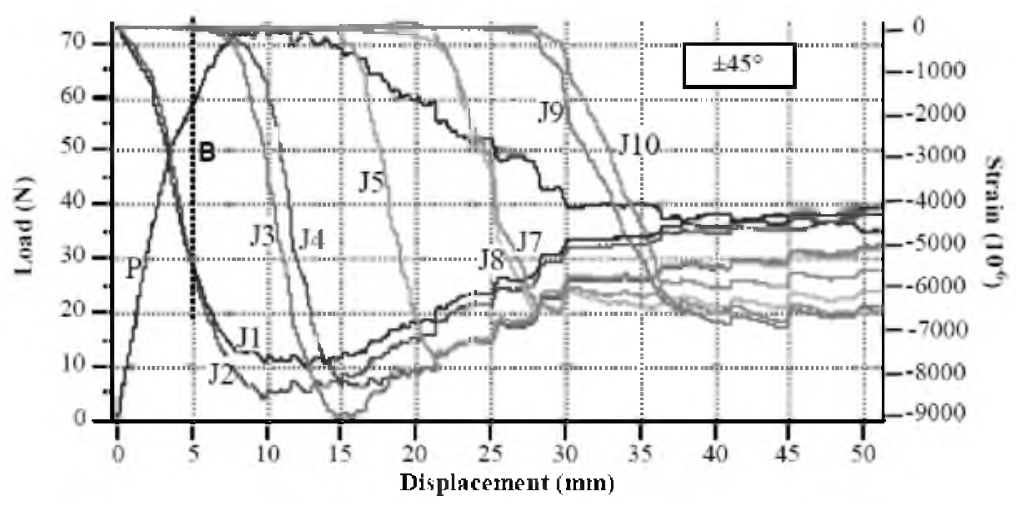

$b$

Fig. 6. Load and strains vs. displacement curves: $\pm 15^{\circ}(a)$ and $\pm 45^{\circ}(b)$.

2.1. Deformation of Material in Front of the Crack Tip. Several studies were carried out in order to estimate the angle of deflection at the crack tip of the arms of anisotropic material DCB [3-5]. They are based upon the beam theory of the elastic Timoshenko concept. The half of DCB specimen can be schematized by a semi-infinite beam, of which the part located in front of the crack tip is sustained on an elastic foundation and is loaded at its free end (see Fig. 7). 


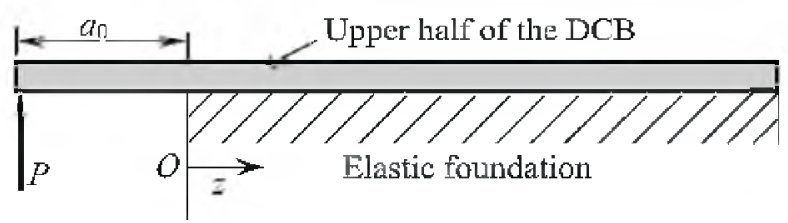

Fig. 7. Schematization of an arm of the DCB

The deflection of the part, which is in contact with the foundation, can be calculated by the following relationship:

For small displacements, the equation of the bent axis of a beam is given by

$$
E_{L} I_{x x} \frac{d^{2} y}{d z^{2}}=-M_{z}
$$

by deriving the Eq. (1) twice, we obtain the distributed load

$$
E_{L} I_{x x} \frac{d^{4} y}{d z^{4}}=q
$$

$q$ represents the reaction of the foundation; $q=k y$, where $k$ is the modulus of foundation and represents the reaction per unit of length when the strain is equal to the unit. It is given by

$$
k=\frac{E_{T} b}{h / 2} .
$$

Therefore

$$
E_{T} I_{x x} \frac{d^{4} y}{d z^{4}}=k y
$$

Putting $\beta^{4}=\frac{k}{4 E_{L} I_{x x}}$, the general solution takes the form

$$
y=e^{\beta z}(A \cos \beta z+B \sin \beta z)+e^{-\beta z}(C \cos \beta z+D \sin \beta z) .
$$

The constants $A, B, C$, and $D$ are given from the boundary conditions. It is obvious to admit that the bending deformation and the moment of flexion equal zero infinitely far away from the force $P$. This can be done by

$$
\left.y(z)\right|_{x=\infty}=e^{\beta z}(A \cos \beta z+B \sin \beta z),
$$

thus $A=B=0$

The expression of the deformation of the right part of the beam becomes then

$$
y(z)=e^{-\beta z}(C \cos \beta z+D \sin \beta z) .
$$


Constant $C$ and $D$ are determined by the origin conditions at $z=0$

$$
\begin{gathered}
E_{L} I_{x x} \frac{d^{2} y}{d z^{2}}(z=0)=-M_{z}=-P a_{0}, \\
E_{L} I_{x x} \frac{d^{3} y}{d z^{3}}(z=0)=-V_{z}=-P,
\end{gathered}
$$

or

$$
\frac{d^{2} y}{d z^{2}}=2 \beta^{2} e^{-\beta z}(C \sin \beta z-D \cos \beta z)
$$

and

$$
\frac{d^{3} y}{d z^{3}}=2 \beta^{3} e^{-\beta z}(C \sin \beta z-D \cos \beta z+C \cos \beta z+D \sin \beta z)
$$

Thus

$$
D=\frac{P a_{0}}{2 \beta^{2} E_{L} I_{x x}} \quad \text { and } \quad C=\frac{P\left(\beta a_{0}-1\right)}{2 \beta^{3} E_{L} I_{x x}} .
$$

The general equation becomes

with

$$
y(z)=\frac{P e^{-\beta z}}{2 \beta^{3} E_{L} I_{x x}}\left(\beta a_{0}(\cos \beta z+\sin \beta z)-\cos \beta z\right)
$$

$$
\beta=\sqrt[4]{\frac{k}{4 E_{L} I_{x x}}}=\sqrt[4]{\frac{6 E_{T^{\prime}}}{E_{L} h^{4}}}
$$

It should be noticed that through this formulation of the deformation, only the thickness of the specimen arm $(h)$ has an effect over the period of the propagation wave of the strained zone ahead of the crack tip. The initial crack length $\left(a_{0}\right)$ has influence on the strain intensity of this zone.

In the case of this study, $b=20 \mathrm{~mm}$ and $h=2.5 \mathrm{~mm}$, the values of $k$ and $\beta$ are summarized in Table 2.

$\mathrm{T}$ a b 1 e 2

Values of $k$ and $\beta$ for the Different Sequences

\begin{tabular}{|c|c|c|c|c|c|}
\hline Sequence & 0 & $\pm 15^{\circ}$ & $\pm 30^{\circ}$ & $\pm 45^{\circ}$ & $\pm 60^{\circ}$ \\
\hline$k \cdot 10^{5}, \mathrm{~N} / \mathrm{mm}^{2}$ & 2.876 & 2.780 & 2.629 & 2.955 & 4.422 \\
\hline$\beta, \mathrm{mm}^{-1}$ & 0.500 & 0.510 & 0.550 & 0.626 & 0.713 \\
\hline
\end{tabular}

The final relationship of deformation of various stacking sequences are shown in Table 3. The experimental loads $P$ taken in the calculation of these deformations correspond to the delamination starting for each sequence of stratification, for a length of initial crack $a_{0}=25 \mathrm{~mm}$. 
Mechanical Behavior and Optimization

T a b 1 e 3

Equations of the Deformations of the Various Sequences

\begin{tabular}{|c|c|c|}
\hline Sequence & $\begin{array}{c}P, \mathrm{~N} \\
\text { (starting) }\end{array}$ & Equations of the deformation \\
\hline $\pm 15^{\circ}$ & 63 & $y(z)=2.32 \cdot 10^{-4} e^{-0.51 z}[12.75(\cos 0.51 z+\sin 0.51 z)-\cos 0.51 z]$ \\
\hline $\pm 30^{\circ}$ & 55 & $y(z)=229 \cdot 10^{-4} e^{-0.55 z}[13.75(\cos 0.55 z+\sin 0.55 z)-\cos 0.55 z]$ \\
\hline $\pm 45^{\circ}$ & 50 & $y(z)=2.118 \cdot 10^{-4} e^{-0.626 z}[15.65(\cos 0.626 z+\sin 0.626 z)-\cos 0.626 z]$ \\
\hline $\pm 60^{\circ}$ & 37 & $y(z)=1.193 \cdot 10^{-4} e^{-0.713 z}[17.825(\cos 0.7136 z+\sin 0.713 z)-\cos 0.713 z]$ \\
\hline
\end{tabular}

The evolution of the deformations of the two halves of the DCB, ahead of the crack tip, of the various sequences can be represented, as an example by the $\pm 15^{\circ}$ sequence illustrated by Fig. 8 . This representation assumes that the DCB specimen is separated into two parts. This figure shows the existence of a strain field located ahead of the crack tip. This can be explained by the fact that the perfect embedding cannot set up at the crack tip but at a distance $d(\approx 10 \mathrm{~mm})$ which is composed by two quite distinct zones: a tension zone ahead of crack tip followed by a compression zone. Although the stacking sequence has an influence on the deformation and on the flexion angle, it does not affect the length of the distance $d$ (Fig. 9). In addition, the thickness of the specimen has a significant effect as well on the intensity of the deformations on their extent. This remark is highlighted by the curves of Fig. 10, where for the same sequence of stratification, the distance $d=10 \mathrm{~mm}$ for $h=2.5 \mathrm{~mm}$ increase to $20 \mathrm{~mm}$ for $h=5 \mathrm{~mm}$ and to $40 \mathrm{~mm}$ for $h=10 \mathrm{~mm}$. In fact, starting from this figure, it should be noted that the surface ranging between the curve of deformation and the axis $z$ changes delimitations but guard the same surface when one increases the thickness of the specimen arms. The increasing of the arm thickness permits to diminish the intensity of the deformation until avoiding any form of energy dissipation in this zone.

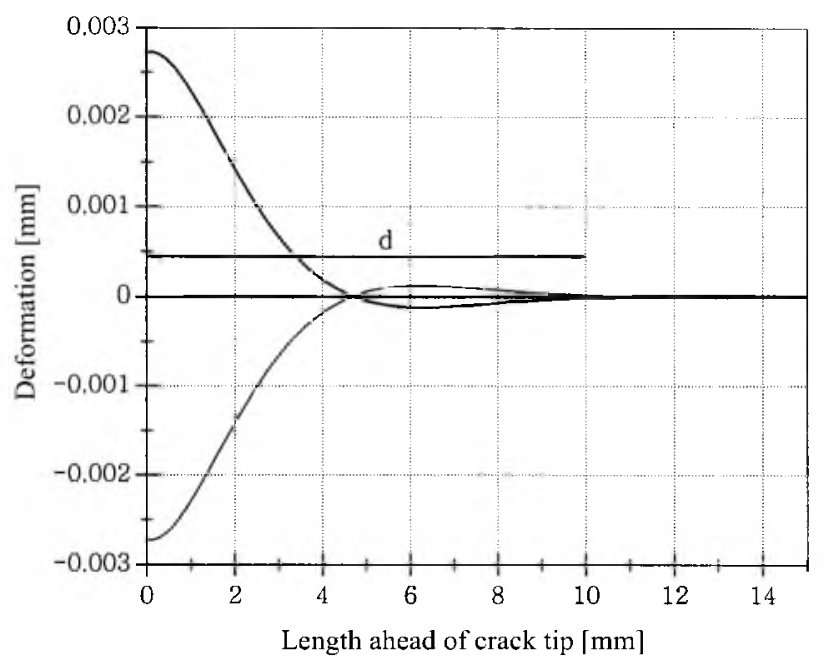

Fig. 8. Deformation of the two arms of $\pm 15^{\circ}$ DCB specimen. 


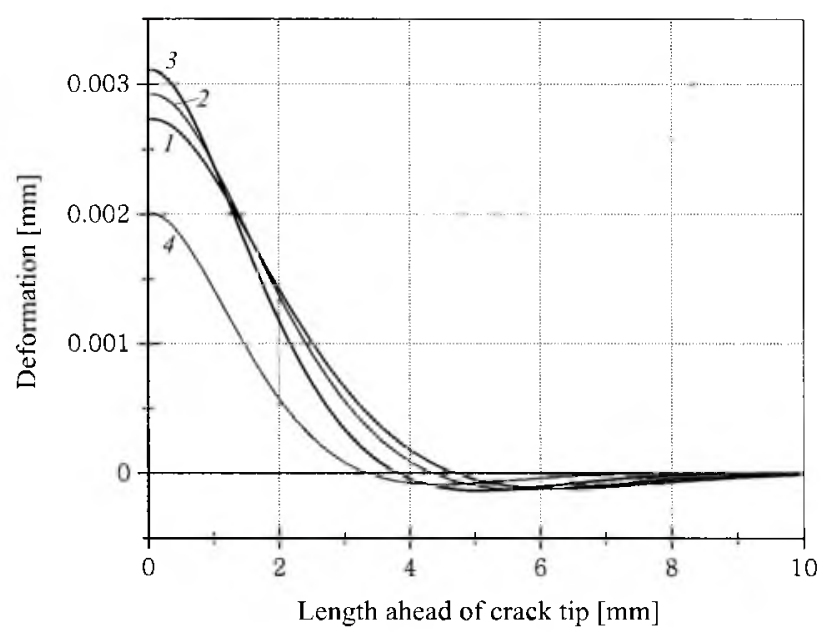

Fig. 9. Deformation for various stacking sequences: (1) $\pm 15^{\circ},(2) \pm 30^{\circ},(3) \pm 45^{\circ},(4) \pm 60^{\circ}$,

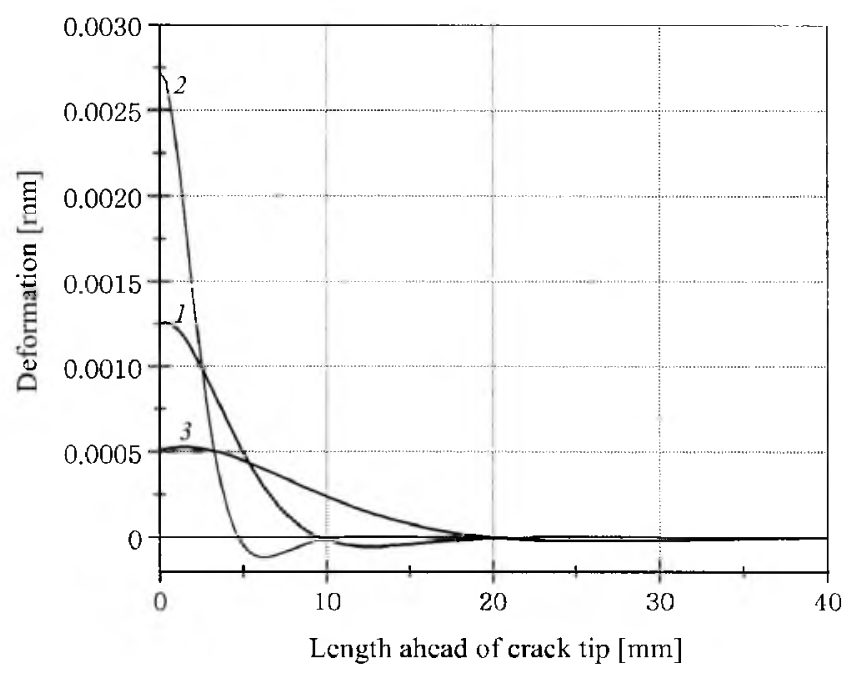

Fig. 10. Thickness effect on deformation ahead the crack tip $[h=5(1), 2.5(2)$, and $10 \mathrm{~mm}(3)]$.

2.2. Non-Linearity Effect. According to Carlsson's studies [6], it seems interesting to study the non-linearities of the DCB specimen behavior. These non-linearities are due primarily to large displacements and micro-cracking by flexion. They are shown by the maximum slope of deflection $y_{m}^{\prime}$ at the point of the load application and by the maximum deformation $\varepsilon_{m}$ corresponding to the rupture by flexion. The non-linearities are satisfied for

$$
y_{m}^{\prime}=y_{a}^{\prime} \quad \text { and } \quad \varepsilon_{m} \leq \varepsilon_{a},
$$

where $y_{a}^{\prime}$ and $\varepsilon_{a}$ are the acceptable values.

Carlsson [6] proposed $y_{a}^{\prime}=1 \%, \varepsilon_{a}$ can be determined by the theory of the first ply failure developed by TSAI. The calculation of these two parameters is performed by considering the static diagram of a DCB arm (Fig. 11). 


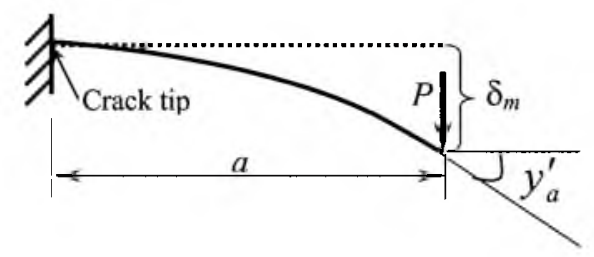

Fig. 11. Static diagram of a DCB arm.

2.2.1. Non-Linearity Due to Large Displacement. $\delta_{m}$ and $y_{m}^{\prime}$ are given according to the beam theory by

$$
\delta_{m}=\frac{8 P a^{3}}{E b h^{3}} \quad \text { and } \quad y_{m}^{\prime}=\frac{6 P a^{2}}{E b h^{3}} .
$$

Thus

$$
\delta_{m}=\frac{2}{3} a y_{m}^{\prime}
$$

where $E$ is the longitudinal modulus of elasticity of material, $b$ is the width of the arm, and $h$ is its thickness. This yields:

$$
\delta_{a}=\frac{2}{3} a y_{a}^{\prime} .
$$

Using Irwin-Kies approach to determine the energy release rate:

$$
G_{\mathrm{Ic}}=\frac{P^{2}}{2 b} \frac{\partial C}{\partial a}
$$

where $P$ is the applied load, $b$ is the specimen width, and $\partial C / \partial a$ is the partial derivative of the compliance with respect to the crack length. Knowing that $C=\frac{\delta}{P}=\frac{8 a^{3}}{E b h^{3}}$ and $\frac{\partial C}{\partial a}=\frac{24 a^{2}}{E b h^{3}}$ (beam theory) for the two arms of the DCB, provides the following relationship between the maximum displacement of the arm and the energy release rate:

$$
\delta_{m}=\frac{2 a^{2}}{\sqrt{3}} \sqrt{\frac{G_{\mathrm{I}}}{E h^{3}}} .
$$

Thus, we can write

$$
\frac{2 a^{2}}{\sqrt{3}} \sqrt{\frac{G_{\mathrm{I} c}}{E h^{3}}} \leq \frac{2}{3} a y_{a}^{\prime} .
$$

This last relationship allows us to determine the minimal thickness of the specimen arm which makes the initiation of delamination without having a large displacement state 


$$
h \geq \sqrt[3]{\frac{3 a^{2} G_{\mathrm{I}_{C}}}{E y_{a}^{\prime}}} .
$$

Noteworthy is that all the parameters, in this relationship, are intrinsic with material, except the initial crack length a which remains an unspecified geometrical characteristic and does not affect the value of $h$ since it will be taken constant in the case of a possible comparison between various stacking sequences.

2.2.2. Non-Linearity Due to Cracking by Flexion. The maximum strain by flexion is given at the embedding of the specimen (crack tip) by

$$
\varepsilon_{m}=\frac{6 P a}{E b h^{2}},
$$

it is related to maximum displacement by

$$
\varepsilon_{m}=\frac{3}{2} \frac{h \delta_{m}}{a^{2}} .
$$

By associating the two equations (10) and (15), we obtain

$$
\varepsilon_{m}=\sqrt{\frac{3 G_{\mathrm{Ic}}}{E h}} .
$$

Thus, and in the same way as for the first condition of non-linearity, the minimal thickness of the specimen arm ensuring initiation of delamination without cracking by flexion can be given by

$$
h \geq \frac{3 G_{\mathrm{I} c}}{E \varepsilon_{a}^{2}} .
$$

For this second condition of non-linearity, all the parameters are intrinsic with material.

2.2.3. Application of This Study to Laminates. The optimal values of the thickness $h$ of the specimen arm calculated according to the first and second condition of non-linearity are summarized in Table 4 . They were calculated for $25 \mathrm{~mm}$ length of initial crack. The values of $G_{I c}$ and $\varepsilon_{a}$, has been already given in [7].

Figure 12 shows the thickness evolution of the arms of the DCB specimen necessary to avoid non-linearities before initiation of delamination according to the angle ply. The analysis of these curves shows that for lower angles of plies orientation (inferior to approximately $38^{\circ}$ ), the non-linearity for low thickness of the specimen arm (approximately $1 \mathrm{~mm}$ ) is given by large displacement. On the other hand, for the angles higher than $38^{\circ}$, the non-linearity by transverse cracking can affect the mechanical behavior. The analysis of these curves also shows that 
Mechanical Behavior and Optimization...

in this study $(h=2.5 \mathrm{~mm})$, transverse cracking before the initiation of delamination appears for plies orientation angle more than $47^{\circ}$. This is in accordance with the experimental results given above.

$\mathrm{T}$ a b 1 e 4

Optimal Thickness of the Specimen Arms for Various Sequences

\begin{tabular}{|c|c|c|c|c|c|}
\hline \multirow{2}{*}{ Sequence } & \multirow{2}{*}{$\varepsilon \cdot 10^{-3}$} & \multirow{2}{*}{$G_{\mathrm{I} c}, \mathrm{~J} / \mathrm{m}^{2}$} & \multirow{2}{*}{$y_{a}^{\prime}, \%$} & \multicolumn{2}{|c|}{$h, \mathrm{~mm}$} \\
\cline { 5 - 6 } & & & & first condition & second condition \\
\hline 0 & 24.55 & 185 & 1 & 0.923 & 0.021 \\
\hline $\pm 15^{\circ}$ & 9.95 & 185 & 1 & 0.965 & 0.145 \\
\hline $\pm 30^{\circ}$ & 6.20 & 185 & 1 & 1.088 & 0.535 \\
\hline $\pm 45^{\circ}$ & 4.00 & 185 & 1 & 1.236 & 1.980 \\
\hline $\pm 60^{\circ}$ & 2.53 & 185 & 1 & 1.283 & 5.277 \\
\hline
\end{tabular}

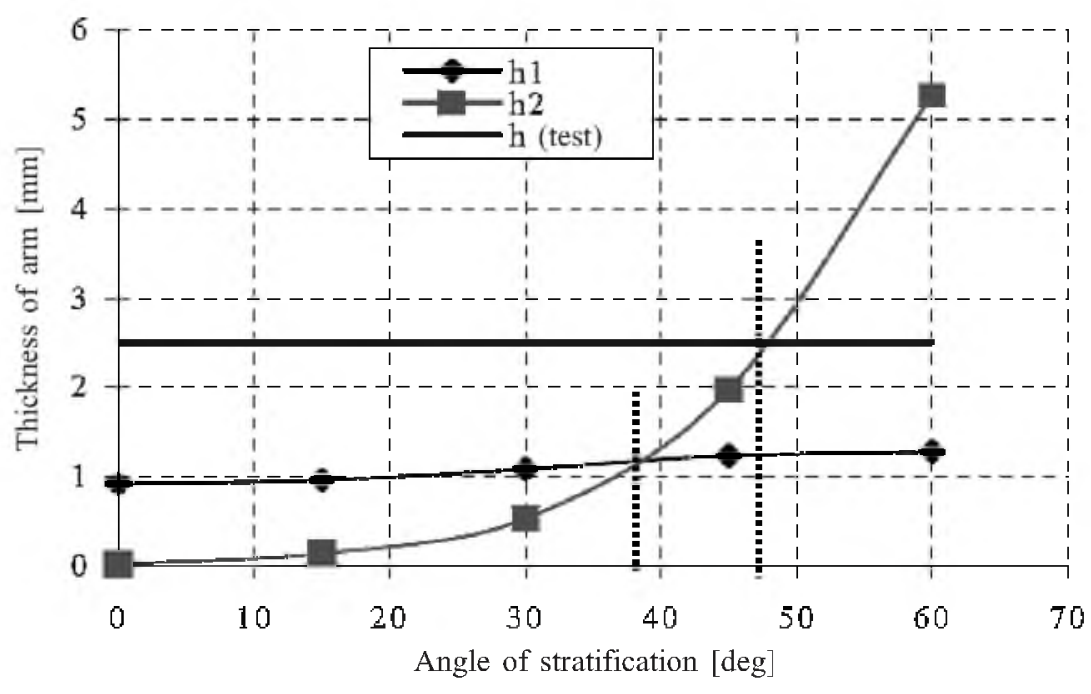

Fig. 12. Thickness optimization for the DCB specimen arm

Conclusions. The objective of this study was the optimization thickness of the DCB specimen, which makes it possible to avoid all non-linearity, especially by transverse cracking, before the initiation of delamination in the multidirectional laminates. The experimental results, according to the response of the strain gauges showed the existence of deformations ahead of crack tip, which explains why embedding is not as perfect as it was assumed. They also showed by microscopic observations, that the initiation of delamination in Mode I of sequence for $2.5 \mathrm{~mm}$ arm thickness is always preceded by a cracking transverse of the more strained one of the two arms of the DCB specimen. As for the analytical results obtained, they are in good agreement with the experimental results, and allowed us the determination of the minimal thickness of DCB specimen, which satisfies the application the Linear Elastic Fracture Mechanics (LEFM) concepts. 


\section{P ез о м е}

При навантаженні згином багатовимірних ламінатів має місце деламінація. Її опис $є$ досить важким, оскільки у вістрі тріщини присутні великі деформації та відмічаються нелінійні ефекти, що зумовлені значними переміщеннями і утворенням поперечних мікротріщин. Останні 3'являються у найбільш навантажених шарах, особливо в тонких ламінатах. Експериментально досліджено вищезгадані особливості на зразках у вигляді консольної балки та виконано оптимізацію товщини багатошарового зразка, за якої деламінація починаєтьсядо утворення поперечних мікротріщин у найбільш навантажених шарах. Об'єктом дослідження служив склоепоксидний зміцнений ламінат. Отримані результати оптимізації товщини зразка добре узгоджуються з експериментальними даними.

1. C. E. Harris and D. H. Morris, A Characterization of the Fracture Behavior of Thick, Notched, Laminated Graphite/Epoxy Composites, VPI Institute and State University, Blacksburg, Grant No. NASA-NAG-1-264 (1983).

2. J. G. Williams, Mode I Transverse Cracking in an Epoxy and Graphite Fiber Reinforced Epoxy, M.S. Thesis Texas A\&M University (1981).

3. J. G. Williams, "End corrections for orthotropic DCB specimen," Compos. Sci. Technol., 35, 367-376 (1989).

4. F. E. Penado, "A closed form solution for the energy release rate of the double cantilever beam specimen with an adhesive layer," J. Compos. Mater., 27, No. 4, 383-407 (1993).

5. R. Olsson, "A simplified improved beam analysis of the DCB specimen," Compos. Sci. Technol., 43, 329-338 (1992).

6. L. A. Carlsson, J. W. Gillespie, and R. B. Pipes, "On the analysis and design of end notched flexure (ENF) specimen for Mode II testing," J. Compos. Mater., 20, 594-604 (1986).

7. A. Ahmed Benyahia, Etude des Mécanismes de Délaminage sous l'Effet de Contraintes Complexe Générées par des Sollicitations Simples d'Ouverture et de Cisaillement dans les Stratifies $\pm \theta$, Thesis, Université de Technologie de Compiègne, No. 1040 (1997).

8. A. Ahmed Benyahia, A. Laksimi, S. Benmedakhene and X. L. Gong, "Fracture process in $\pm \theta$ laminates subjected to Mode II loading," Strength Mater., 34, No. 4, 390-401 (2002).

9. A. Laksimi, A. Ahmed Benyahia, M. L. Benzeggagh, X. L. Gong, "Initiation and bifurcation mechanisms of cracks in multi-directional laminates," Compos. Sci. Technol., 60, 597-604 (2000). 